\title{
Epidemiology of acute hepatitis B in a university hospital in São Paulo, Brazil: retrospective study of two five-year periods
}

\author{
Discipline of Gastroenterology, Universidade Federal de São Paulo/Escola Paulista de Medicina - São Paulo, Brazil
}

\begin{abstract}
Context: HBV infection is endemic in Brazil and acute HBV infection is still a common disease. Objective: To analyze incidence, risk factors and evolution of acute HBV infection. Setting: University Hospital. Patients: 357 patients with acute HBV infection, comparing two periods: 1985-1989 vs. 1990-1994. Results: The overall incidence declined from 50 new cases/year in 1985-89 (30\% of all cases) to 25 new cases/year in 1990-94 (8\% of all cases). Transmission among male homosexuals (3.9\% of cases in $85-89)$ declined to $1.3 \%$ in $90-94(p>0.05)$. Amongst health care workers (HCW) it declined from $8.2 \%$ to $2.0 \%(p=0.02)$. Conversely, heterosexual transmission increased from $4.8 \%$ to $10.1 \%(p=0.06)$. Chronification of HBV infection following the acute episode was observed in $1.7 \%$. Fulminant hepatic failure was seen in $3.4 \%$. However, $27.2 \%$ of patients were lost to follow-up before normalization of the biochemical tests. Conclusions: The different patterns of risk factors observed is probably related to measures for preventing AIDS and to HCW vaccination programs. Chronification following acute episodes was not a common event.
\end{abstract}

UNITERMS: Hepatitis. Hepatitis B. Acute hepatitis B. Epidemiology.

\section{INTRODUCTION}

$\mathrm{H}$ epatitis B virus (HBV) is one of the major causes of acute and chronic hepatitis in the world..$^{(1)}$ It is considered to be the most versatile of all hepatotropic viruses, often producing acute infections with or without jaundice, chronic hepatitis possibly progressing to cirrhosis of the liver, or even a state of asymptomatic

\section{Address for correspondence:}

Maria Lucia Gomes Ferraz

Rua Machado Bittencourt 413 apto 81

São Paulo/SP - Brasil - CEP 04044-001 carrying of the infection. In addition, HBV may cause fulminating hepatitis and plays an important role in the genesis of hepatocellular carcinoma in the chronic forms of the infection. ${ }^{(2)}$

The natural course of hepatitis B can be documented by the determination of serologic markers of the infection whose profiles are characteristic for acute, chronic or fulminating infection. ${ }^{(3)}$

The control of HBV infection is currently possible with the use of highly safe and effective vaccines against hepatitis B.$^{(4)}$ However, most infections occur among adults belonging to risk groups such as intravenous drug users and male homosexuals, who are difficult to approach for participation in vaccination programs. ${ }^{(5)}$ Furthermore, the 
changing epidemiology of HBV infections complicates even more the problem of the elaboration of adequate programs for the prophylaxis of this disease.

In view of the above considerations, when adequate programs for the control of HBV infection are elaborated, it is important to be aware of the epidemiologic profile of the infection in the different populations to be approached. Thus, the objective of the present study was to investigate the incidence of acute HBV hepatitis in patients who sought a public health care service in a university hospital in the city of São Paulo and to determine the routes of transmission and forms of evolution of the disease, as well as possible changes in the epidemiologic pattern over a period of 10 years.

\section{METHODS}

\section{Study population}

A retrospective study was conducted on all the patients who sought the Hepatitis Outpatient Clinic of the Discipline of Gastroenterology, Escola Paulista de Medicina, from January 1985 to December 1994 and who were diagnosed as having HBV-induced acute hepatitis. This diagnosis was based on clinical history and biochemical evaluation and was confirmed by HBsAg and anti-HBc IgM antibody positivity.

Following these criteria, patients with a diagnosis of acute hepatitis B were classified by sex, age, year of onset of the acute disease, possible route of transmission and form of evolution of the disease.

For the characterization of evolutive patterns the patients were classified into one of the following categories after a follow-up of at least six months: 1. biochemical normalization (ALT and AST), HBsAg negativity and appearance of anti-HBs antibodies; 2. negativity of $\mathrm{HBsAg}$ but without the appearance of anti-HBs antibodies; 3 . biochemical normalization and abandonment of followup before serologic reevaluation; 4. abandonment of follow-up before biochemical normalization; 5. evolution to chronic disease (persistence of HBsAg for more than 6 months); 6. fulminating course.

\section{Procedures}

All the charts from included patients were analyzed in relation to demographic data, route of transmission (transfusion, intrafamily contact, heterosexual contact, health professionals, intravenous drug use, homosexuality, tattoos or undetermined).

ALT and AST levels were determined by an automated kinetic method using reagents from Roche (normal ALT up to $41 \mathrm{UI} / \mathrm{L}$ and normal AST up to 38 $\mathrm{UI} / \mathrm{L})$.

The presence of serologic markers (HBsAg, anti-HBc IgM and anti-HBs) was determined by an immunoenzymatic technique using Abbot kits (AUSZYME, CORZYME and AUSAB).

\section{Statistical analysis}

Data were analyzed statistically by the chi-square test, Fisher's exact test and the Student t-test, with the level of significance set at 0.05 .

\section{RESULTS}

A total of 2702 patients with various forms of acute and chronic hepatitis were seen at the Hepatitis Outpatient Clinic of Escola Paulista de Medicina from January 1985 to December 1994. Of these, 357 (13\%) fulfilled the diagnostic criteria of acute hepatitis B; 200 $(56 \%)$ were males and 157 (44\%) females, ranging in age from 14 to 78 years (mean age: 32 years; median: 42.5 years). Most patients (67\%) were in the 20 to 40 year age range (Figure 1).

Most cases of acute HBV hepatitis were concentrated in the 1985-1990 period, corresponding to $30 \%$ of the total number of cases seen in the sector. A progressive and significant decline in the contribution of acute hepatitis B to the total number of cases seen was observed thereafter, with a rate of only 8\% of all cases from 1991 to 1994 . Figure 2 shows the occurrence of hepatitis B over the years and the total number of patients seen annually at the service.

The possible routes of transmission were: transfusion $(8.7 \%)$, intrafamily $(7.8 \%)$, heterosexual $(7.0 \%)$, health professional $(5.6 \%)$, intravenous drugs $(5.3 \%)$, homosexual $(2.8 \%)$, and tattoos $(1.2 \%)$. The possible route of transmission could not be determined in $61.6 \%$ of cases.

When the two major study periods were compared (1985-1989 vs 1990-1994), transmission by the heterosexual route was found to have increased from $4.8 \%$ to $10.1 \%$ of cases $(\mathrm{p}=0.06)$, whereas the homosexual route decreased from $3.9 \%$ to $1.3 \%(\mathrm{p}>0.05)$. Similarly, transmission among health professionals decreased significantly from $8.2 \%$ to $2.0 \%$ ( $\mathrm{p}=0.02$ ), whereas cases 


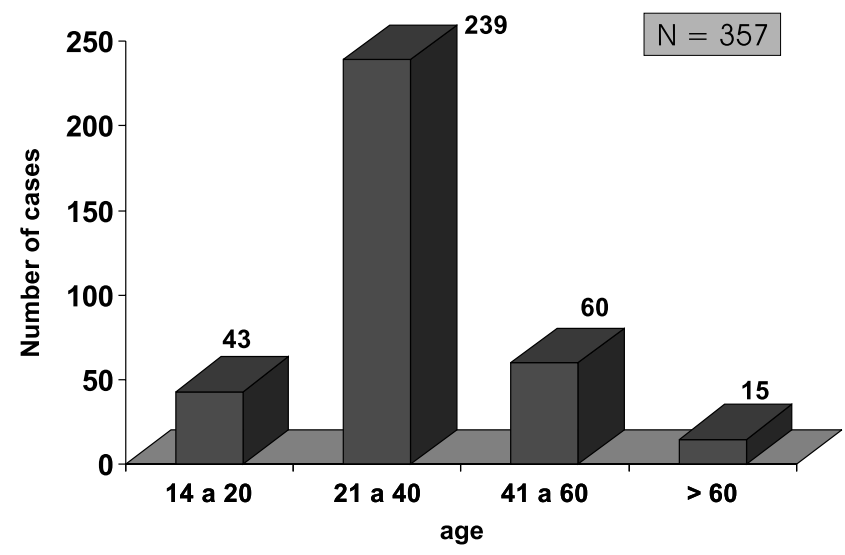

Figure 1. Distribuition of patients with acute hepatitis $B$, according to the age.

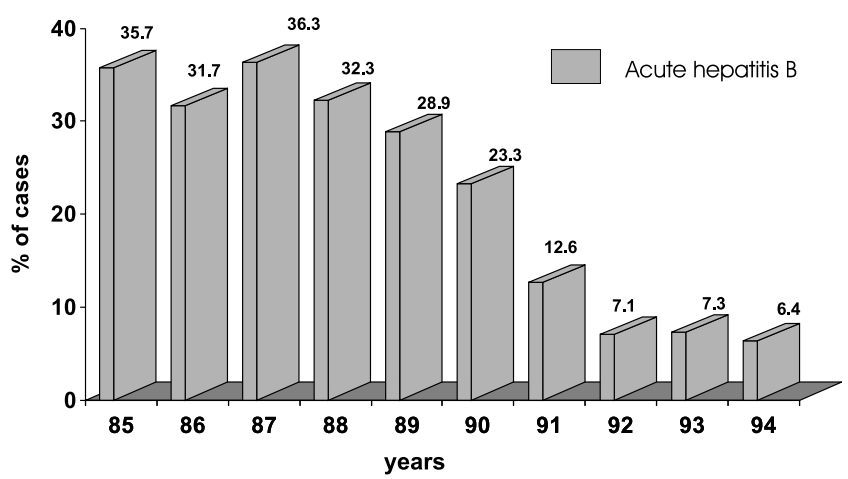

Figure 2. Occurence of acute hepatitis B over the years at a University Hospital in São Paulo, Brazil.

of unknown transmission increased from $54.8 \%$ to $71.1 \%$ $(\mathrm{p}<0.005)$ (Figure 3).

The rate of chronicity of the disease was $1.7 \%$ and a fulminating course occurred in $3.4 \%$ of cases. Of the 357 patients studied, 123 complied with the recommended full follow-up, including serologic evaluation after the cure. Of these, 14\% (16/123) did not show positivity for antiHBs antibodies despite having become negative for HBsAg.

\section{DISCUSSION}

The prevalence of HBV infection in Brazil is intermediate, with a rate of chronic carriers of the virus ranging from $0.5 \%$ to $5 \% .{ }^{(6)}$ However, the country has regions of high prevalence, with more than a $10 \%$ rate of chronic carriers in certain populations studied in the Western Amazon region. ${ }^{(7)}$
HBV is mainly transmitted by percutaneous or mucosal membrane exposure to infectious body fluids. ${ }^{(8)}$ Although the HBV surface antigen (HBsAg) can be demonstrated in a wide variety of body fluids, only blood and semen are potentially infectious. Percutaneous exposures resulting in $\mathrm{HBV}$ transmission include transfusion of blood or blood derivatives, shared use of needles and syringes for intravenous drug injection, hemodialysis, acupuncture, and professional contact with infected patients. ${ }^{(9)}$

Sexual and perinatal transmission of hepatitis B, in turn, occurs by contact of mucosal membranes with infectious blood or body fluids. ${ }^{(10)}$

The fact that effective measures are currently available for the control of HBV infection justifies a careful analysis of the trends shown by the routes of transmission and the evolution of the disease over the last few years.

The present demographic data showing a discrete predominance of men and a higher incidence in the 20 to 40 year age range agree with the literature. Most studies have shown a sex ratio of 1.3:1 to 2:1. ${ }^{(11,12)}$ In most studies, the peak of incidence of the disease occurs among adolescents and young adults, suggesting an important role for the sexual route in the transmission of infection. ${ }^{(12)}$

As for the transmission routes, in most cases we could not identify a risk factor, although the sexual route cannot be ruled out under these circumstances. We only classified as possible cases of heterosexual transmission those in which the partner was known to be a carrier of the disease or those that reported two or more sex partners over the preceding six months.

The present study revealed that the incidence of acute hepatitis B has progressively declined over the last few years. The possible explanations for this fact could be, first, the onset of AIDS with the consequent dissemination of measures for the control and prevention of the disease at a population-wide level. These measures, aimed at the avoidance of parenteral and sexual transmission of AIDS,

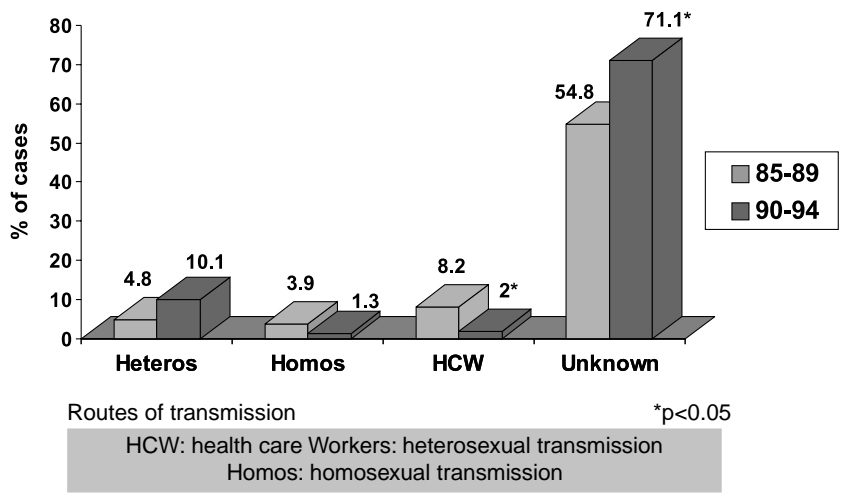

Figure 3. Transmission routes for acute hepatitis B: comparison between two periods of five years. 
have resulted in reducing the incidence of hepatitis $\mathrm{B}$, since the two diseases share similar routes of transmission and risk groups.

Studies conducted in other countries have reported similar findings, with a sharp change in the epidemiologic profile of the infection over the last few years. ${ }^{(13)}$

In addition, the application of effective vaccines against hepatitis B to specific risk groups, especially health professionals, has contributed to the overall reduction in the number of cases. ${ }^{(14)}$

These observations are even more evident when we compare the two study periods (1985-1989 vs. 1990-1994), with a sharp decrease in the number of infections among health professionals, a fact that, in our service, can definitely be attributed to the vaccination campaigns carried out within the São Paulo Hospital and Escola Paulista de Medicina, starting in 1988. A comparison of the two periods also showed a reduced incidence of cases among male homosexuals, a fact that may be attributed to measures for the prevention of AIDS.

Similar data were observed in the U.S., where HBV infection predominated among male homosexuals during the period from 1982 to 1985 , followed by heterosexually infected individuals and intravenous drug users, in that order. From 1986 to 1988 this pattern changed, with a predominance of the disease among drug users and a predominance of heterosexual over homosexual transmission. Cases of hepatitis B among health professionals also declined during the same period as a consequence of the vaccination campaigns. ${ }^{(15)}$ The patients who do not present identifiable risk factors represent a serious public health problem since they are usually excluded from immunization programs which, for cost reasons, have long been limited to groups at risk of contracting the infection. This problem, allied to the fact that the risk of chronicity is much higher among children, justifies the tendency to immunize all children during the first year of life in all First World countries.

Regarding evolutionary aspects, in our series there was a high percentage (3.4\%) of cases with a fulminating course. Data in the literature suggest that approximately $1 \%$ of all cases of hepatitis B follow a fulminating course. We attribute this higher percentage to the fact that our service is a reference center to which more severe cases or patients with other complications associated with acute hepatitis B are referred.

Few data are available in the literature about the characteristics of the host or of the viral agent that might be related to different forms of evolution of the disease. In the case of fulminating evolution, genomic variations of HBV, together with different degrees of host immune response, seem to be an important determinant. ${ }^{(16)}$

Although a large number of patients abandoned follow-up, a fact that impairs the evolutionary analysis of the disease, we observed that chronicity after an episode of acute hepatitis was infrequent (1.7\%), confirming data reported by others. ${ }^{(17,18)}$ In a recent metanalysis study ${ }^{(19)}$ involving 10 papers published on the subject, the risk of chronicity after HBV infection was $>10 \%$ in 2 studies, $5 \%$ in 1 and $<5 \%$ in the remaining 7 (being less than $1 \%$ in 5 of them). In 3 of these studies the population consisted of patients with acute jaundiced hepatitis whose rate of chronicity was $2 \%$. The factors related to the tendency to chronicity usually involve host properties, i.e. genetic, hormonal and nutritional characteristics, although factors linked to the virus such as route of infection and viral load also seem to play an important role.

Post-infection serologic follow-up was possible only for $123 / 357$ patients even though all patients were instructed to return to the service after the sixth month of disease, reflecting the low level of compliance of this population, probably due to its precarious socioeconomic level. Fourteen percent of the patients did not show positivity for anti-HBs antibodies although they had become negative for HBsAg. It should be pointed out that all of these 16 patients were retested for anti-HBs antibody 3 months later and all were found to be still negative. Thus, they started to present a serologic profile with anti-HBc antibody alone. The presence of isolated anti-HBc antibodies has also been observed in approximately $15 \%$ of all blood donors and the present study confirms that many of these donors may have had acute HBV infection and did not show positivity for anti-HBs antibodies, despite the negativity for HBsAg. ${ }^{(20)}$ Further studies are needed to determine all the elements that influence the development of the different evolutionary forms of HBV infection, whose epidemiologic characteristics and natural history should be investigated whenever possible. 


\section{RESUMO}

Contexto: A infecção pelo vírus B é endêmica no Brasil e a infecção aguda pelo HBV ainda é freqüente. Objetivo: Analisar a incidência, fatores de risco e formas evolutivas da hepatite aguda B. Local: Hospital universitário. Participantes: 357 pacientes com hepatite B aguda, comparando dois períodos distintos: 1985-1989 vs. 1990-1994. Resultados: A incidência caiu de 50 casos novos/ano em $85-89$ ( $30 \%$ de todos os casos atendidos), para 25 casos novos/ano ( $8 \%$ dos casos). A transmissão entre homossexuais caiu de $3,9 \%$ dos casos em $85-89$ para 1,3\% em $90-94$ ( $p>0.05$ ). Entre profissionais de saúde, caiu de $8,2 \%$ para 2,0\% ( $p=0,02)$; Inversamente, a transmissão heterossexual aumentou de 4,8\% para 10,0\% ( $p=0,06)$. Cronificação seguindo um episódio agudo de hepatite B ocorreu em 1,7\% dos casos. Hepatite fulminante ocorreu em 3,4\% dos casos; entretanto, $27,2 \%$ dos pacientes abandonaram o seguimento antes da normalização da ALT. Conclusões: A mudança do padrão epidemiológico se deveu, possivelmente, às medidas de proteção adotadas contra a AIDS e à vacinação de profissionais de saúde. A ocorrência de cronificação após o episódio agudo foi pouco freqüente.

\section{REFERENCES}

1. Margolis HS, Alter J, Hadler SC. Hepatitis B: evolving epidemiology and implications for control. Semin Liver Dis 1991;11:84-92.

2. Beasley RP. Hepatitis B virus: the major etiology of hepatocellular carcinoma. Cancer 1988; 61:1942-56.

3. Hoofnagle JH, Di Bisceglie A. Serologic diagnosis of acute and chronic hepatitis. Semin Liver Dis 1991; 2:3-83.

4. Andre F. Overview of a 5-year clinical experience with a yeast-derived hepatitis B vaccine. Vaccine 1990; 8:S74-8.

5. Francis DP. The public's health unprotected: reversing a decade of underutilization of hepatitis B vaccine. JAMA 1995; 274(15):1201-8.

6. Carrilho FJ, Silva LC. Epidemiologia. In: Silva LC. Hepatites agudas e crônicas. $2^{a}$ ed. São Paulo: Sarvier; 1995:73-95.

7. Gayotto LCC, Quarentei AA, Cabral GL. Soroepidemiologia das hepatites A e B nas áreas dos rios Biá e Alto Juruá, Amazonia Ocidental. GED 1984; 3:106-16.

8. Tabor E. Viral hepatitis: epidemiology and prevention. In: Berk JE. Bocku's gastroenterology. 4th ed. Philadelphia: Saunders; 1985:2811-24.

9. Lauer JL, Van Drumen NA, Washbun JW. Transmission of hepatitis B virus in clinical laboratory areas. J Infect Dis 1979; 140:513-6.

10. Alter M, Ahtone J, Weisfuse I, Starko K, Vacalis TD, Maynard JE. Hepatitis B virus transmission between heterosexuals. JAMA 1986; 256(10):1307-10.

11. Osmon DR, Melton LJ, Keyes TF, et al. Viral Hepatitis: a population-based study in Rochester, MN, 1971-1980. Arch Intern Med 1987; 147:1235-1240.
12. McQuillan GM, Townsend TR, Fields HA, Leahy BS, Polk BF. Seroepidemiology of hepatitis B virus infection in the United States. Am J Med 1989; 87 (suppl 3A):5S-10S.

13. Squarcione S, Pompa MG, Vellucci L, Virtuani L. Epidemiology of hepatitis B in Italy by reports to the National Surveillance System. IX Triennial International Symposium on Viral Hepatitis and Liver Disease (Abstracts). April, 2125, 1996. A-237, p.107.

14. Frider B, Sookonian S, Rebora N. Professional risk: hepatitis $B$ vaccination strategies in a general hospital. Acta Gastroenterol Latinoam 1992; 22:29-35.

15. Alter MJ, Hadler SC, Margolis HS, Alexander WJ, Hu PY, Judson FN, et al. The changing epidemiology of hepatitis B in the United States. JAMA 1990; 263(9):1218-22.

16. Terazawa S, Kojima M, YamanakaT, et al. Hepatitis B virus mutants with precore region defects in two babies with fulminant hepatitis and their mothers positive for antibody to hepatiis B and antigen. Pediatr Res 1991; 29:5-9.

17. Rinker J, Calambos J. Prospective study of hepatitis B in thirty two inadvertently infected people. Gastroenterology $1981 ; 81: 686-91$

18. Roumeliotou A, Papavangelou G. Chronic liver disease rarely follows acute hepatitis $\mathrm{B}$ in non-immunocompromised adults. Infection 1992; 20(4):221-3.

19. Hyams KC. Risks of chronicity following acute hepatitis B virus infection: a review. Clin Infect Dis 1995; 20: 9921000.

20. Koff RS. Difficult serologic diagnosis in viral hepatitis. In: Hollinger FB, Lemon SM, Margolis H, editors. Viral hepatitis and liver disease. Baltimore: Williams \& Wilkins; 1991:790-1. 